\title{
Metal ion complexation in acetonitrile by upper-rim benzyl-substituted, di-ionized calix[4]arenes bearing two dansyl fluorophores
}

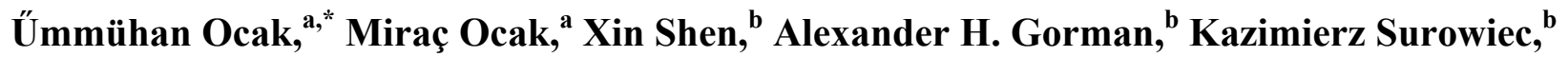 \\ and Richard A. Bartsch \\ ${ }^{a}$ Department of Chemistry, Faculty of Arts and Sciences, Karadeniz Technical University, 61080 \\ Trabzon, Turkey \\ ${ }^{\mathrm{b}}$ Department of Chemistry and Biochemistry, Texas Tech University, Lubbock, Texas 79409, \\ USA \\ E-mail: ummuhanocak@gmail.com
}

\begin{abstract}
The influence of $\mathrm{Li}^{+}, \mathrm{Na}^{+}, \mathrm{K}^{+}, \mathrm{Rb}^{+}, \mathrm{Cs}^{+}, \mathrm{Mg}^{2+}, \mathrm{Ca}^{2+}, \mathrm{Sr}^{2+}, \mathrm{Ba}^{2+}, \mathrm{Ag}^{+}, \mathrm{Cd}^{2+}, \mathrm{Co}^{2+}, \mathrm{Fe}^{2+}, \mathrm{Hg}^{2+}$, $\mathrm{Mn}^{2+}, \mathrm{Pb}^{2+}, \mathrm{Zn}^{2+}$ and $\mathrm{Fe}^{3+}$ on the spectroscopic properties of two dansyl (1dimethylaminonaphthalene-5-sulfonyl) groups linked to the lower rims of a series of three, structurally related, di-ionized calix[4]arenes is investigated by means of emission spectrophotometry. Di(tetramethylammonium) salts of the di-ionized ligands, $\mathbf{L}, \mathbf{L 1}$ and $\mathbf{L 2}$, which differ in having no, two and four benzyl groups, respectively, on the upper rim of the calix[4]arene scaffold, are utilized for the spectrofluorimetric titration experiments in MeCN. On complexation by alkaline earth metal cations, the emission spectra undergo marked red shifts. Alkali metal cations cause fluorescence enhancement of benzyl-substituted di-ionized calix[4] arenes $\mathbf{L 1}$ and $\mathbf{L} 2$ with red shifts, except for $\mathrm{Li}^{+}$and $\mathrm{Cs}^{+}$. Transition metal cations and $\mathrm{Pb}^{2+}$ interact strongly with the ligands. In particular, $\mathrm{Fe}^{3+}, \mathrm{Hg}^{2+}$ and $\mathrm{Pb}^{2+}$ cause greater than $99 \%$ quenching of the dansyl fluorescence for all three ligands.
\end{abstract}

Keywords: Calixarene ligand, fluorescence spectroscopy, stability constant, metal ion complexation

\section{Introduction}

Calixarene-based fluorescent sensors utilize calixarene units as molecular scaffolds for the construction of selective ionophores. ${ }^{1-6}$ Various chemosensors based on calix[4]arenes bearing fluorescent groups have been synthesized for investigation of their fluorescent responses upon complexation with metal cations. ${ }^{7-10}$ Several photoinduced mechanisms have been proposed to 
explain the changes in fluorescent properties of the fluorophore group upon metal complexation, such as electron transfer (PET), charge transfer (PCT), energy transfer and excimer or exciplex formation or disappearance.

Calix[4]arenes possess a hydrophobic upper rim and a hydrophilic lower rim. They can exist in four different conformations: cone, partial cone, 1,2-alternate and 1,3-alternate. ${ }^{11}$ Among these, the cone conformation is used most widely for functionalization. Therefore, studies related to the cone conformation are more frequently encounted than the other conformations. ${ }^{12-14}$ The conformation of the calix[4]arene scaffold is important for metal ion complexation. ${ }^{15}$ Also, substituents on the upper and/or lower rims may influence the metal ion complexation process. The complex may form due to hydrogen bonding, hydrophobic bonding or electron donoracceptor interactions.

In an earlier study, we reported the interactions of didansyl-pendent, di-ionized calix[4]arenes with zero, two and four allyl groups on the upper rim (Figure 1) with a variety of metal cation species using spectrophotometric and spectrofluorimetric techniques. ${ }^{16}$

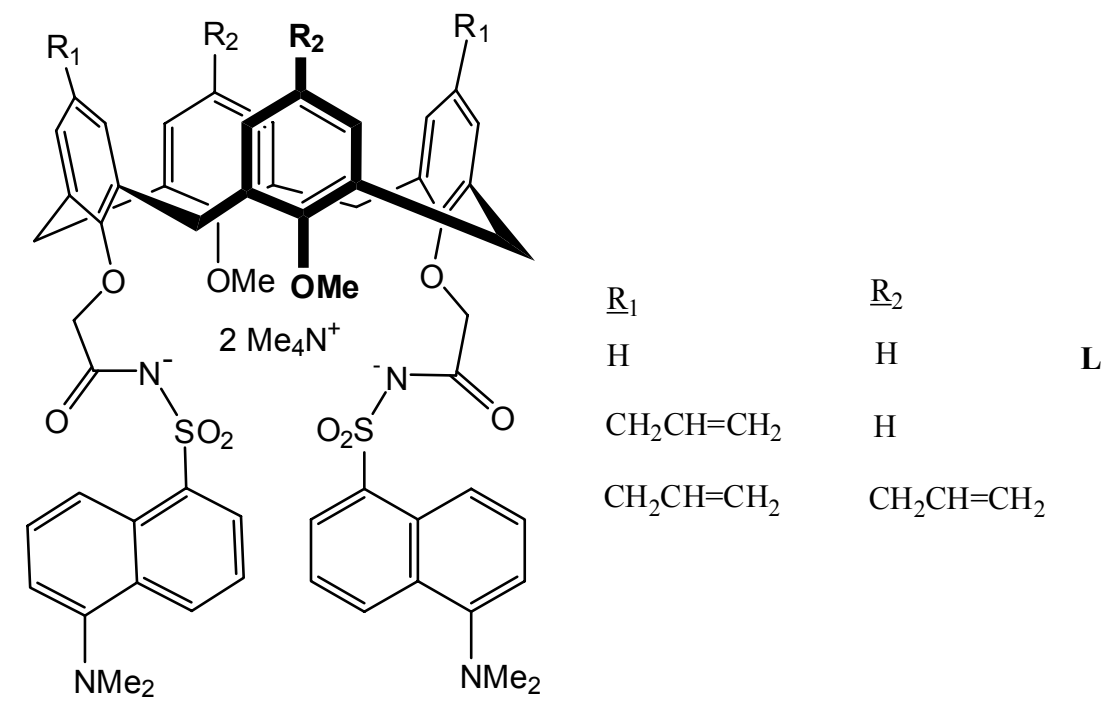

Figure 1. Structures of previously examined di-ionized, didansyl calix[4]arene ligands.

In the present paper, we report the synthesis of two new calix[4]arene ligands $\mathbf{1}$ and $\mathbf{2}$ (Figure 2) with two pendent dansyl groups on the lower rim and two and four benzyl groups, respectively, on the upper rim and complexation properties of their di-ionized forms $\mathbf{L 1}$ and $\mathbf{L 2}$ with metal cations. Compared with the earlier investigated upper-rim allyl groups in the ligand series shown in Figure 1, upper-rim benzyl groups are more bulky and provide additional $\pi$ bonds as potential interaction sites for metal ions. Responses of di(tetramethylammonium) salts of the di-ionized ligands $\mathbf{L 1}$ and $\mathbf{L 2}$ to a variety of metal cations are assessed by spectrofluorometric titration in $\mathrm{MeCN}$. Changes in the fluorescence spectra of $\mathbf{L 1}$ and $\mathbf{L} \mathbf{2}$ in the presence of various metal cations are compared with those reported earlier for $\mathbf{L}$, an analog with 
no benzyl groups on the upper rim. Stability constants and compositions of complexes of $\mathrm{Hg}^{2+}$, $\mathrm{Pb}^{2+}$ and $\mathrm{Fe}^{3+}$ with $\mathbf{L 1}$ and $\mathbf{L 2}$ are determined. A Stern-Volmer approach is utilized to probe the quenching mechanism.
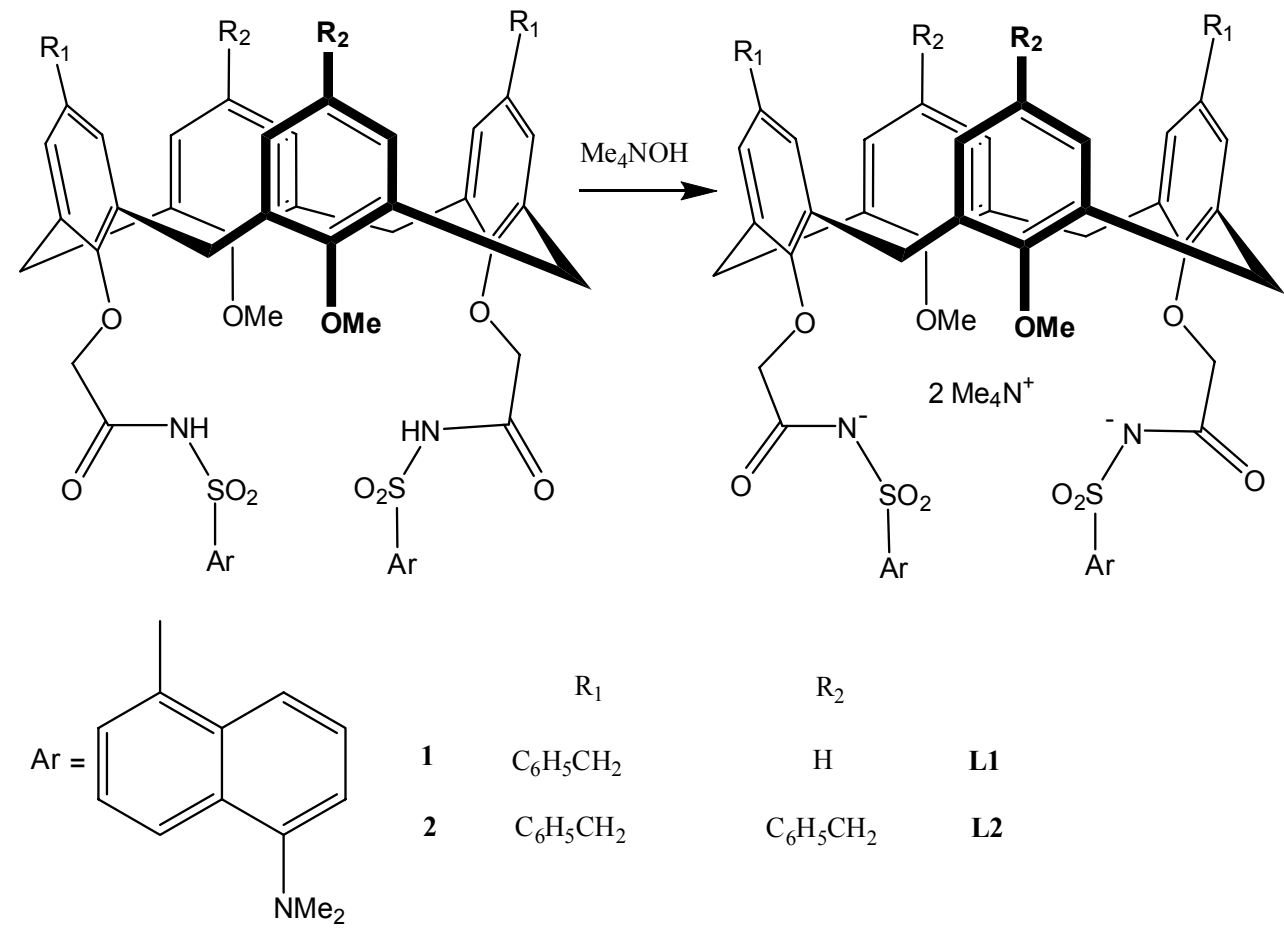

Figure 2. Structures of new didansyl calix[4]arene ionophores $\mathbf{1}$ and $\mathbf{2}$ and their di-ionized tetramethylammonium salts $\mathbf{L} \mathbf{1}$ and $\mathbf{L} 2$, respectively.

\section{Results and Discussion}

\section{Ligand synthesis}

The syntheses of new di-dansylated, di-ionizable calix[4]arene ligands $\mathbf{1}$ and $\mathbf{2}$ are summarized in Schemes 1 and 2, respectively.

For the preparation of ligand 1 with two benzyl groups on the upper rim of the calix[4]arene scaffold (Scheme 1), two methyl groups were attached to distal hydroxyl groups of calix[4]arene 3 to give known diether 4. Friedel-Crafts acylation of 4 with benzoyl chloride and $\mathrm{AlCl}_{3}$ in $\mathrm{CH}_{2} \mathrm{Cl}_{2}$ gave an $81 \%$ yield of the known disubstitution product 5. Attempted Wolff-Kishner reduction of the two benzoyl groups in $\mathbf{5}$ was unsuccessful. However, reduction of $\mathbf{5}$ to the upper-rim dibenzyl compound $\mathbf{6}$ in $90 \%$ yield was achieved with triethylsilane in trifluroacetic acid. Dialkylation of 6 with ethyl bromoacetate and $\mathrm{NaH}$ in THF gave a 71\% yield of diester 7, which was hydrolyzed to diacid 8 in $97 \%$ yield with $\mathrm{Me}_{4} \mathrm{NOH}$ in aqueous THF. Diacid 8 was treated with oxalyl chloride in benzene to produce the corresponding di(acid chloride), which 
was added to the sodium salt of dansylamide in THF to give the di-dansylated calix[4]arene $\mathbf{1}$ in $30 \%$ yield.
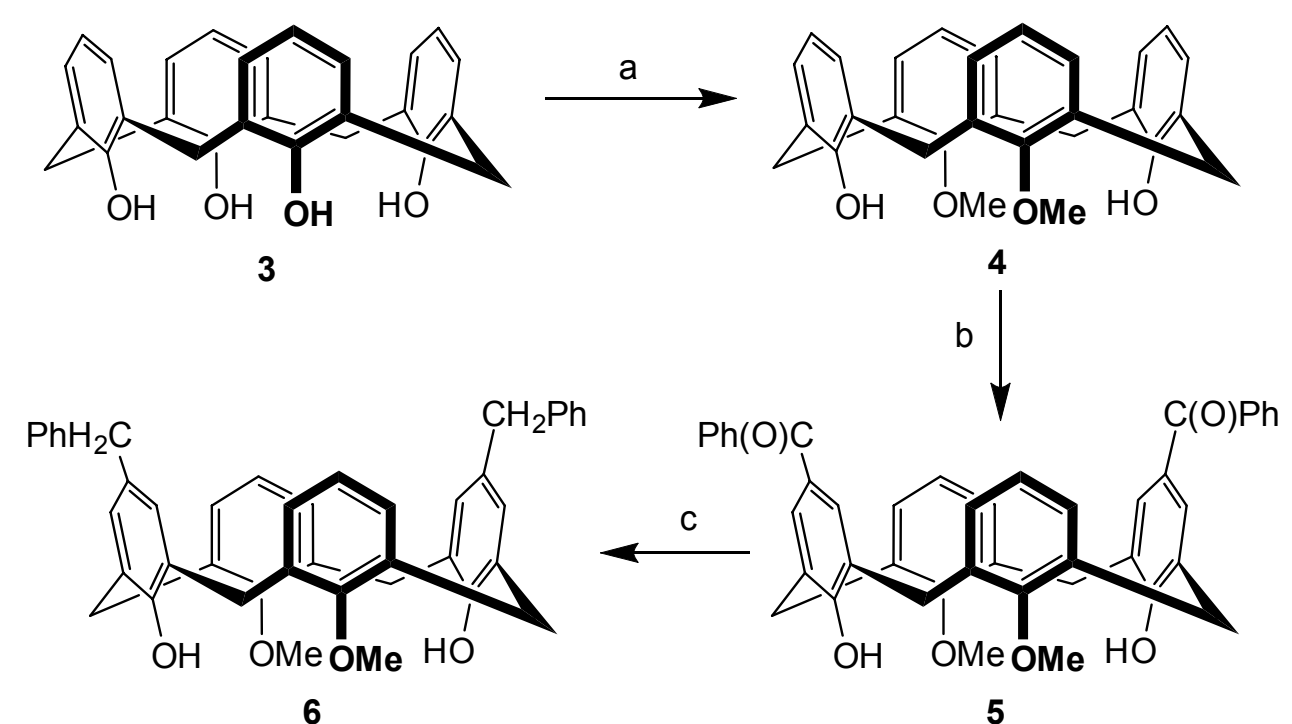

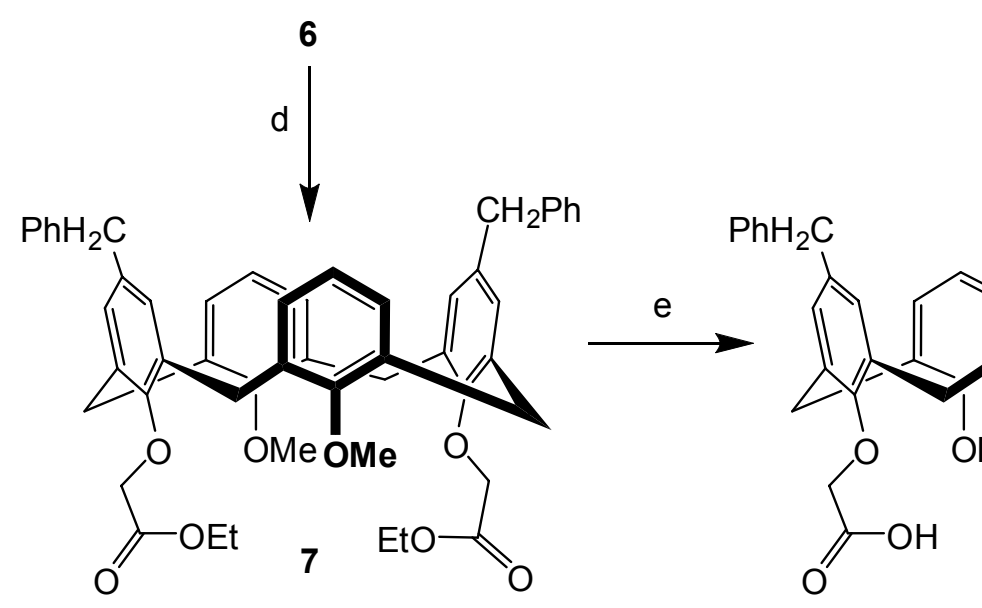

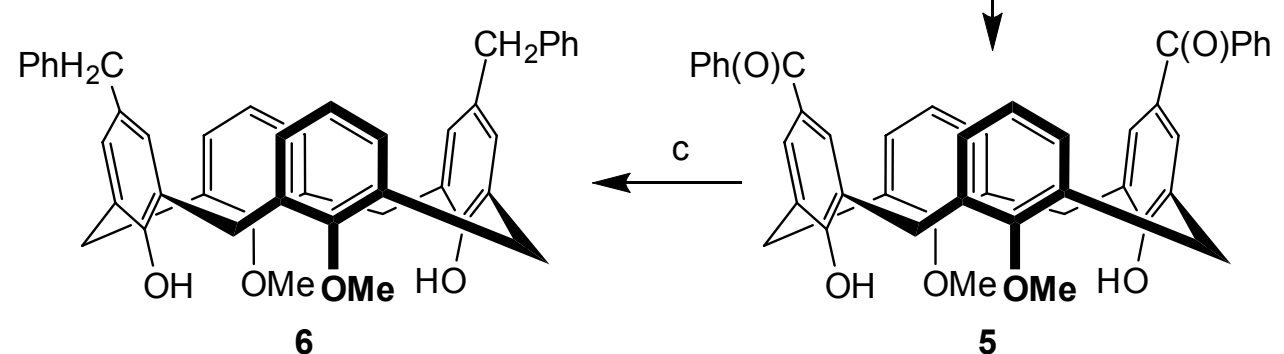

5

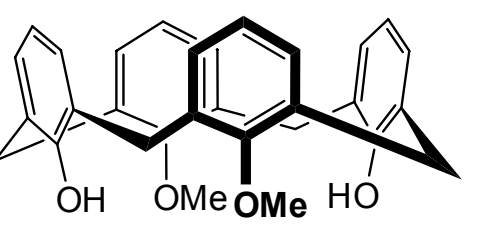

4
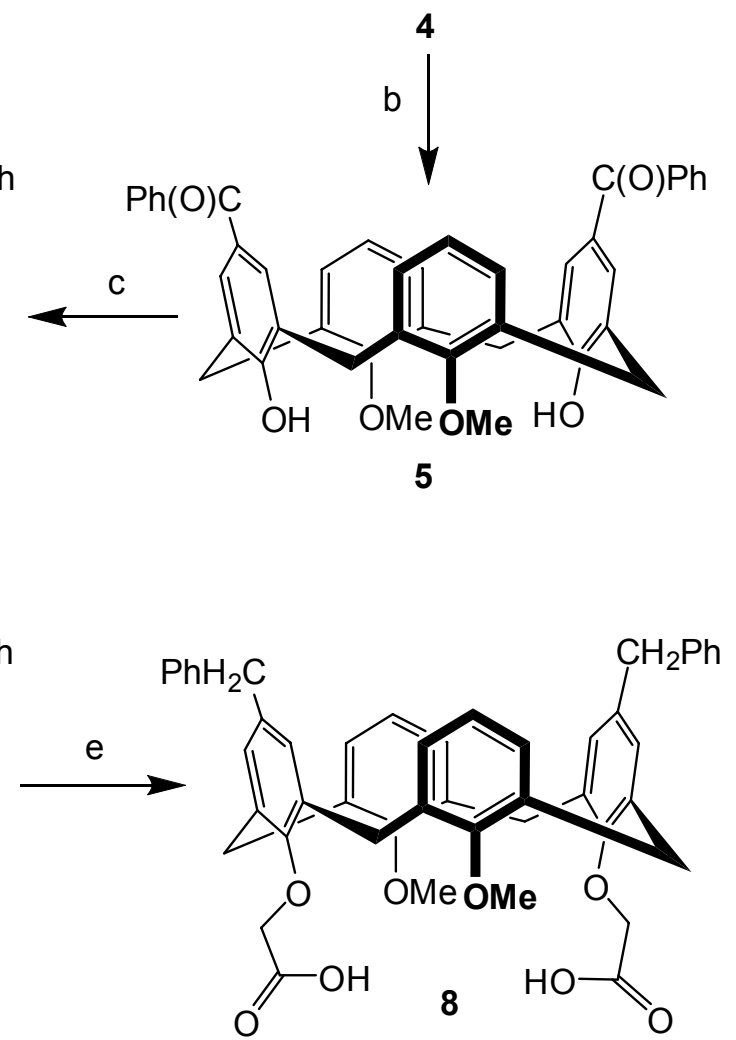

i) $f$
ii) $g$

Scheme 1. Synthesis of didansyl di-ionizable calix[4]arene ionophore 1 with two upper-rim benzyl groups: (a) MeOTs, $\mathrm{K}_{2} \mathrm{CO}_{3}, \mathrm{MeCN}$, reflux, 20 h; (b) $\mathrm{PhC}(\mathrm{O}) \mathrm{Cl}, \mathrm{AlCl}_{3}, \mathrm{CH}_{2} \mathrm{Cl}_{2}, \mathrm{rt}, 24$ h; (c) $\mathrm{Et}_{3} \mathrm{SiH}, \mathrm{CF}_{3} \mathrm{CO}_{2} \mathrm{H}, \mathrm{rt}, 5 \mathrm{~h}$; (d) $\mathrm{BrCH}_{2} \mathrm{CO}_{2} \mathrm{Et}, \mathrm{NaH}, \mathrm{THF}, \mathrm{rt}, 12 \mathrm{~h}$; (e) $10 \%$ aq $\mathrm{Me}_{4} \mathrm{NOH}, \mathrm{THF}$, reflux, 12 h; (f) $(\mathrm{COCl})_{2}$, benzene, reflux, 5 h; (g) dansylamide, NaH, THF, rt, 12 h.

For the synthesis of ligand $\mathbf{2}$ with four benzyl groups attached to the upper rim of the calix[4]arene scaffold (Scheme 2), calix[4] arene 3 was reacted with benzoyl chloride and $\mathrm{AlCl}_{3}$ in $\mathrm{CH}_{2} \mathrm{Cl}_{2}$ to give the tetrabenzoylated tetrabenzoate ester, which was subjected to basic hydrolysis with $\mathrm{NaOH}$ in aqueous $\mathrm{MeOH}$ to remove the ester functions. ${ }^{17}$ An $89 \%$ yield of the 
tetrabenzoylated calix[4]arene 9 was realized. The benzoyl groups were converted into benzyl groups by reaction with hydrazine hydrate and $\mathrm{K}_{2} \mathrm{CO}_{3}$ in triethylene glycol to produce a $95 \%$ yield of known tetrabenzylated calix[4]arene 10. Reaction of $\mathbf{1 0}$ with $\mathrm{K}_{2} \mathrm{CO}_{3}$ and $\mathrm{MeI}$ in $\mathrm{MeCN}$ gave a $91 \%$ yield of diether 11, which was transformed into diester $\mathbf{1 2}$ in $90 \%$ yield by reaction with ethyl bromoacetate and $\mathrm{NaH}$ in THF. Treatment of diester 12 with $\mathrm{Me}_{4} \mathrm{NOH}$ in aqueous THF produced diacid 13 in 97\% yield. Diacid 13 was treated with oxalyl chloride in benzene to produce the corresponding di(acid chloride), which was added to the sodium salt of dansylamide in THF to give the di-dansylated calix[4]arene 2 in $40 \%$ yield.
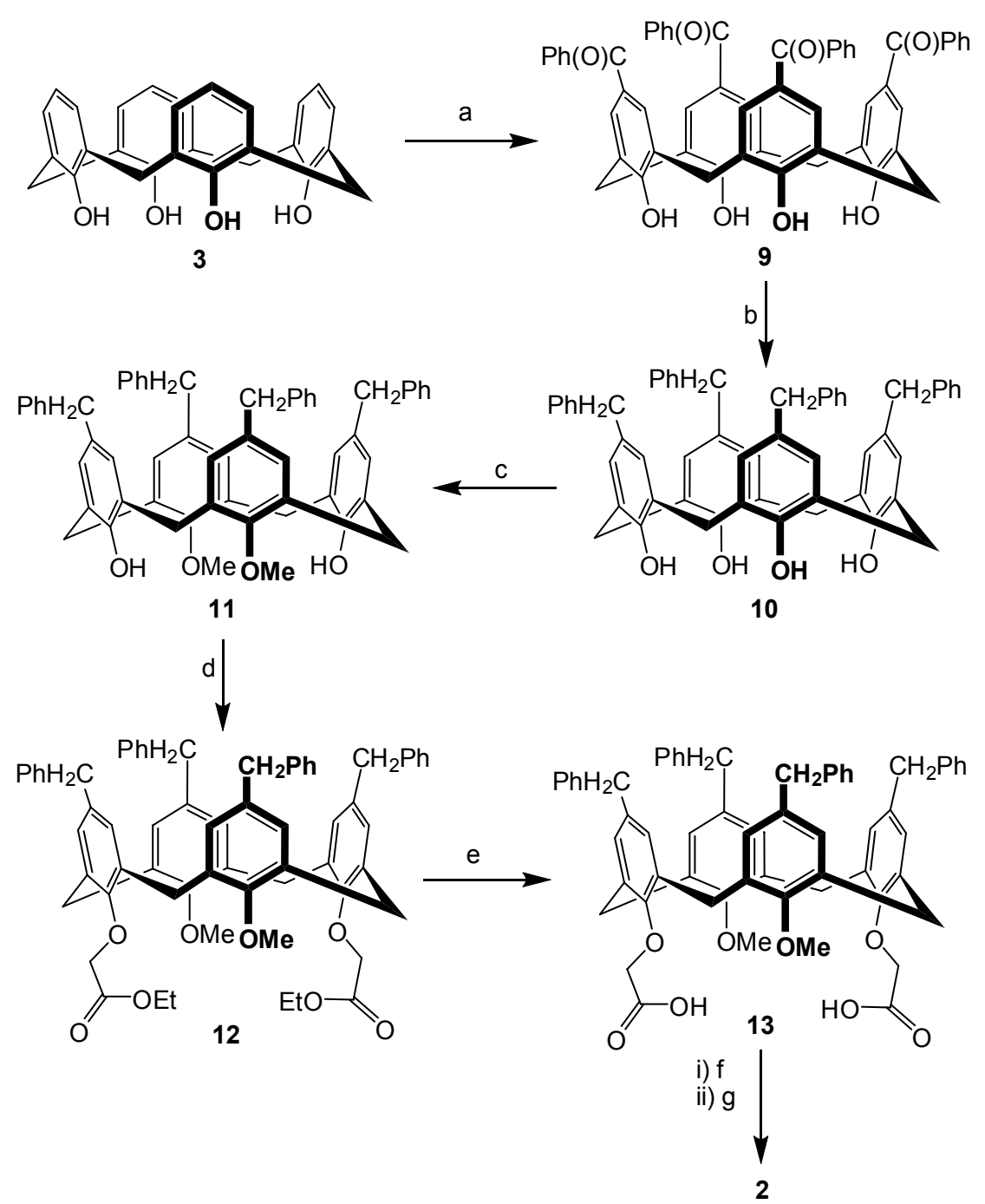

Scheme 2. Synthesis of didansyl di-ionizable calix[4]arene ionophore 2 with four upper-rim benzyl groups: (a) $\mathrm{PhC}(\mathrm{O}) \mathrm{Cl}, \mathrm{AlCl}_{3}, \mathrm{CH}_{2} \mathrm{Cl}_{2}, \mathrm{rt}, 24 \mathrm{~h}$, then $\mathrm{NaOH}$, aq $\mathrm{MeOH}$, reflux 2 days; (b) $\mathrm{NH}_{2} \mathrm{NH}_{2} \cdot \mathrm{H}_{2} \mathrm{O}, \mathrm{K}_{2} \mathrm{CO}_{3}$, triethylene glycol; (c) MeI, $\mathrm{K}_{2} \mathrm{CO}_{3}, \mathrm{MeCN}$, reflux, $20 \mathrm{~h}$; (d) $\mathrm{BrCH}_{2} \mathrm{CO}_{2} \mathrm{Et}$, THF, rt, $12 \mathrm{~h}$; (e) $\mathrm{Me}_{4} \mathrm{NOH}$, aq THF, reflux, $12 \mathrm{~h}$; (f) $(\mathrm{COCl})_{2}$, benzene, reflux, 5 h; (g) dansylamide, NaH, THF, rt, $12 \mathrm{~h}$. 
Structures of new compounds 1, 2, 6 and 11-13 were verified by their ${ }^{1} \mathrm{H}$ NMR, ${ }^{13} \mathrm{C}$ NMR and IR spectra and by combustion analysis. The ${ }^{1} \mathrm{H}$ NMR spectra of new ionophores $\mathbf{1}$ and $\mathbf{2}$ showed broad, poorly defined absorptions revealing conformational mobility in $\mathrm{CDCl}_{3}$ solution. Ligands $\mathbf{1}$ and $\mathbf{2}$ were converted into their di(tetramethylammonium) salts $\mathbf{L 1}$ and L2, respectively, by a reported method. ${ }^{18}$

\section{Fluorescence spectra}

When excited at $328 \mathrm{~nm}$ in MeCN, ligands $\mathbf{L 1}$ and $\mathbf{L 2}$ gave emission bands with maxima at 484 and $482 \mathrm{~nm}$, respectively. Figure 3 shows the effects of 50 equivalents of metal cations on the fluorescence spectra of L1. As can be seen from Figure 3a, the emission band intensities increased somewhat in the presence of alkali metal cations with red shifts of the emission band from that of $\mathbf{L 1}$, except for $\mathrm{Li}^{+}$. Earlier, we observed quenching with alkali metal cations for analogous allyl-substituted ligands. ${ }^{16}$ As can be seen in Figure 3a, the largest red shift was produced by $\mathrm{Li}^{+}$. Similar results were obtained for alkali metal cations with $\mathbf{L 2}$ (Figure 4a). Thus it was found that increasing the number of benzyl groups on the upper rim from two to four did not change significantly the effect of alkali metal cations on the emission spectra. Previously, we obtained similar results with allyl groups on the upper rim. ${ }^{16}$

The emission band intensity for $\mathbf{L 1}$ was diminished substantially with red shifts for the alkaline earth metal cations (Figure 3b). The effects of $\mathrm{Ba}^{2+}$ and $\mathrm{Sr}^{2+}$ and of $\mathrm{Ca}^{2+}$ and $\mathrm{Mg}^{2+}$ on the fluorescence spectra are nearly the same for each pair of metal ions. There are larger red shifts and greater quenching for $\mathrm{Mg}^{2+}$ and $\mathrm{Ca}^{2+}$. In this case, the responses to $\mathrm{Mg}^{2+}$ and $\mathrm{Ca}^{2+}$ were similar. For $\mathbf{L} \mathbf{2}$ in the presence of alkaline earth metal cations, the effect was also substantial quenching with red shifts (Figure $4 \mathrm{~b}$ ). The quenching effect of $\mathrm{Mg}^{2+}$ was even greater. It is interesting that allyl and benzyl groups on the upper rim caused nearly same effect on the fluorescence spectra for interactions with alkali metal and alkaline earth metal cations. ${ }^{16}$

The effects of transition metal cations and $\mathrm{Pb}^{2+}$ on the fluorescence spectra of $\mathbf{L} \mathbf{1}$ and $\mathbf{L} 2$ are presented in Figures 3c and 4c, respectively. Strong quenching of the fluorescence of $\mathbf{L} 1$ and $\mathbf{L 2}$ was observed in the presence of the transition metal cations and $\mathrm{Pb}^{2+}$. However, $\mathbf{L} 2$ caused greater quenching for all transition metal cations and $\mathrm{Pb}^{2+}$ (Figure $4 \mathrm{c}$ ). In particular, $\mathrm{Fe}^{3+}, \mathrm{Hg}^{2+}$ and $\mathrm{Pb}^{2+}$ cause greater than $99 \%$ quenching of the dansyl fluorescence for both ligands $\mathbf{L} \mathbf{1}$ and L2. 

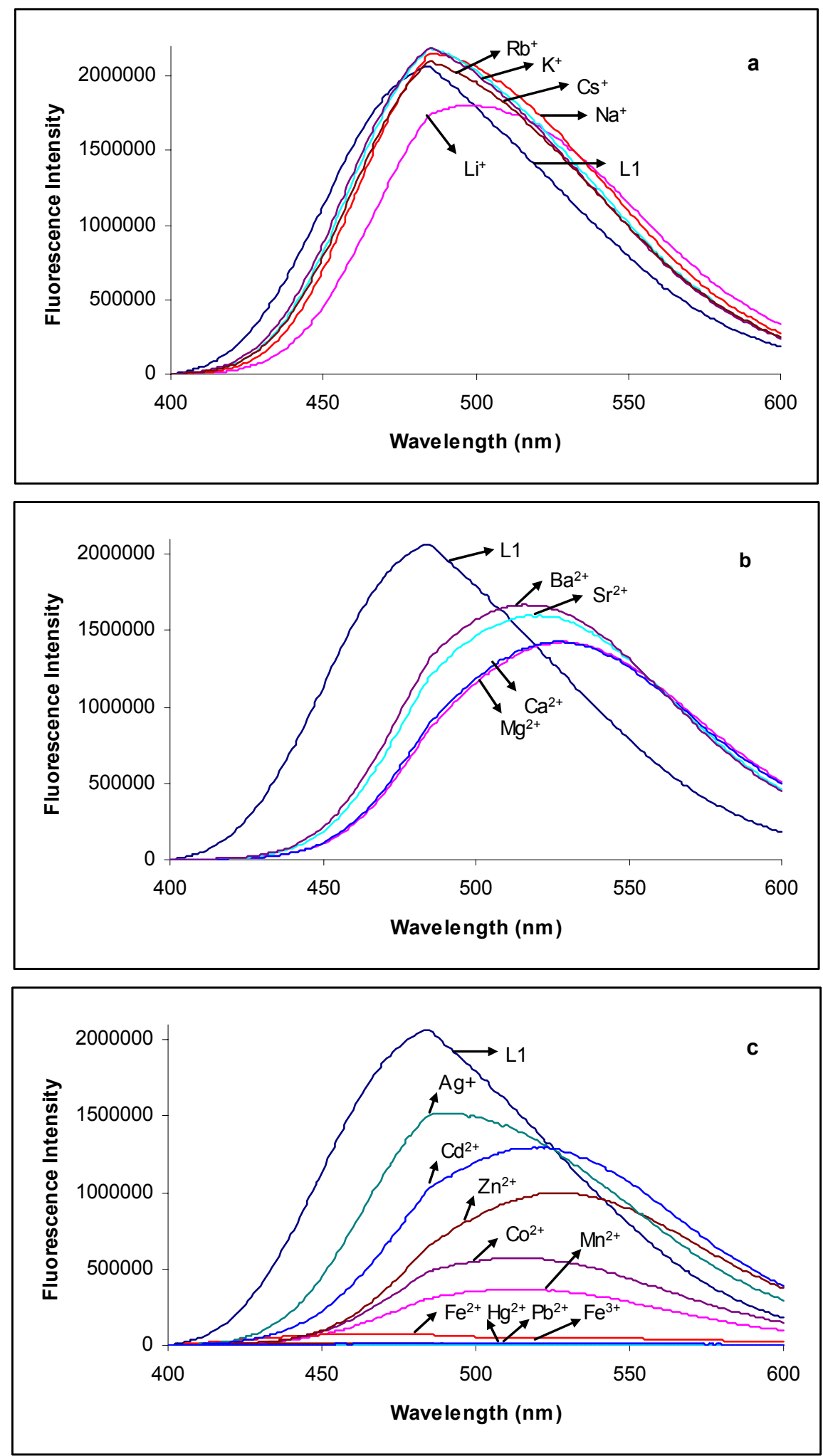

Figure 3. Effect of metal cations on the fluorescence spectra of $\mathbf{L 1}$ in $\mathrm{MeCN}$ : (a) for alkali metal cations; (b) for alkaline earth metal cations ; (c) for transition metal cations and $\mathrm{Pb}^{2+}$. 

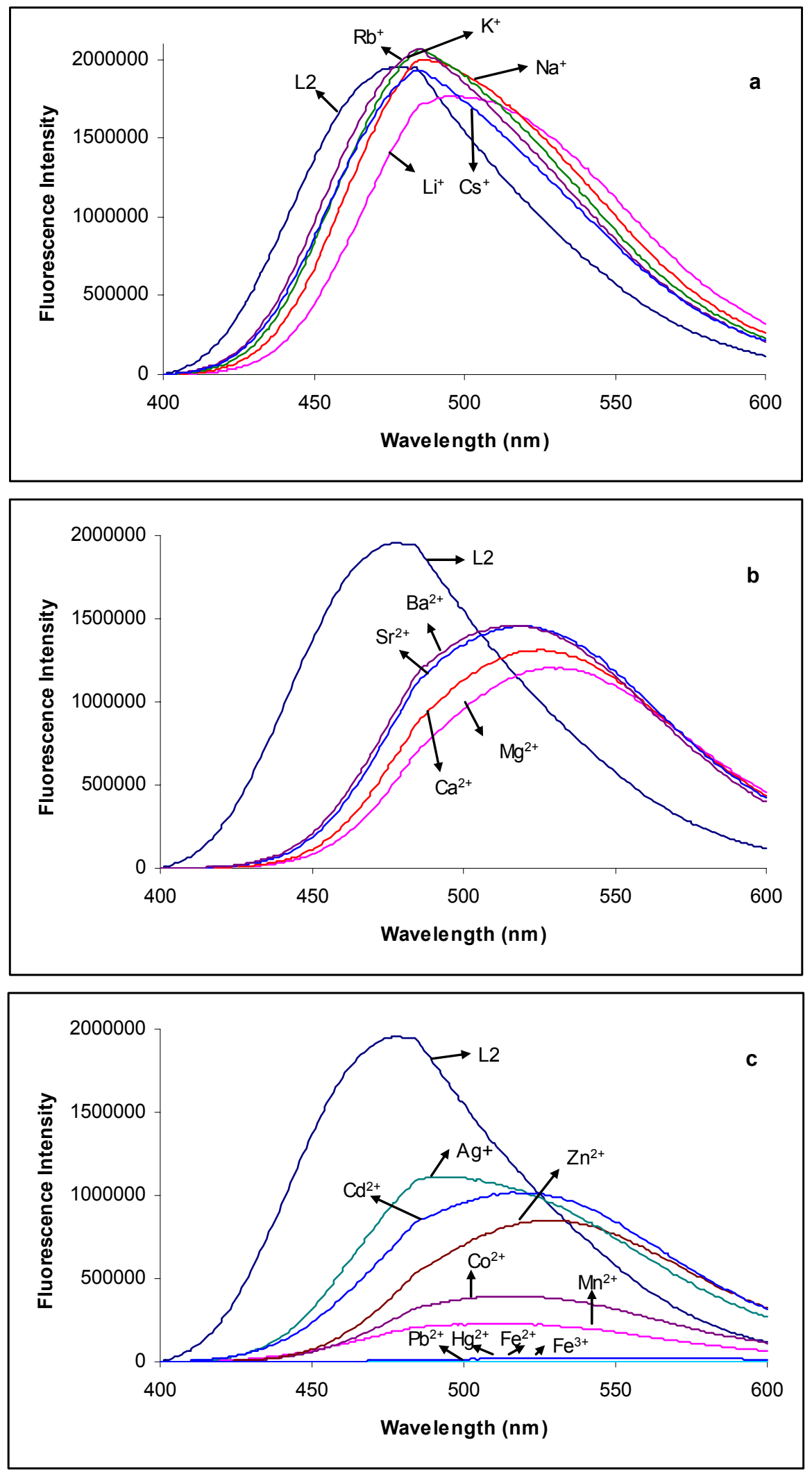

Figure 4. Effect of metal cations on the fluorescence spectra of $\mathbf{L} 2$ in $\mathrm{MeCN}$ : (a) for alkali metal cations; (b) for alkaline earth metal cations ; (c) for transition metal cations and $\mathrm{Pb}^{2+}$. 


\section{Determination of stability constants}

Stability constants and stoichiometries for complexation of $\mathrm{Hg}^{2+}, \mathrm{Pb}^{2+}$ and $\mathrm{Fe}^{3+}$ by ligands $\mathbf{L 1}$ and $\mathbf{L} \mathbf{2}$ in $\mathrm{MeCN}$ were determined by spectrofluorimetric titration. The ligand concentration was held constant at $2.58 \times 10^{-5} \mathrm{M}$. Stoichiometries of the complexes and their stability constants were determined from changes in the fluorescence intensity as a function of the metal ion concentration. Successive decreases of emission with increases of the metal ion concentration were observed in all of the fluorimetric titrations.

Figure 5 shows the fluorescence spectra of $\mathbf{L} 2$ in $\mathrm{MeCN}$ with increasing concentrations of $\mathrm{Fe}^{3+}$. The inserts in Figure 5 are a plot of $\mathrm{I}_{\mathrm{o}}-\mathrm{I} v s$. the ratio of $[\mathrm{M}] /[\mathrm{L}]$ and a plot of the quantity $\mathrm{I}_{\mathrm{o}} /\left(\mathrm{I}_{\mathrm{o}}-\mathrm{I}\right)$ versus $1 /[\mathrm{M}]$. The break in the former at $\left.\mathrm{M}\right] /[\mathrm{L}]=1.0$ provides strong evidence for formation of a 1:1 complex. Similar plots were found with $\mathrm{Pb}^{2+}$ and $\mathrm{Hg}^{2+}$ for $\mathbf{L} \mathbf{1}$ and $\mathbf{L} 2$ in MeCN. The stability constant for a complex was obtained from a plot of the quantity $\mathrm{I}_{\mathrm{o}} /\left(\mathrm{I}_{\mathrm{o}}-\mathrm{I}\right)$ versus $1 /[\mathrm{M}]$. The ratio of intercept/slope gave the stability constant. ${ }^{19}$

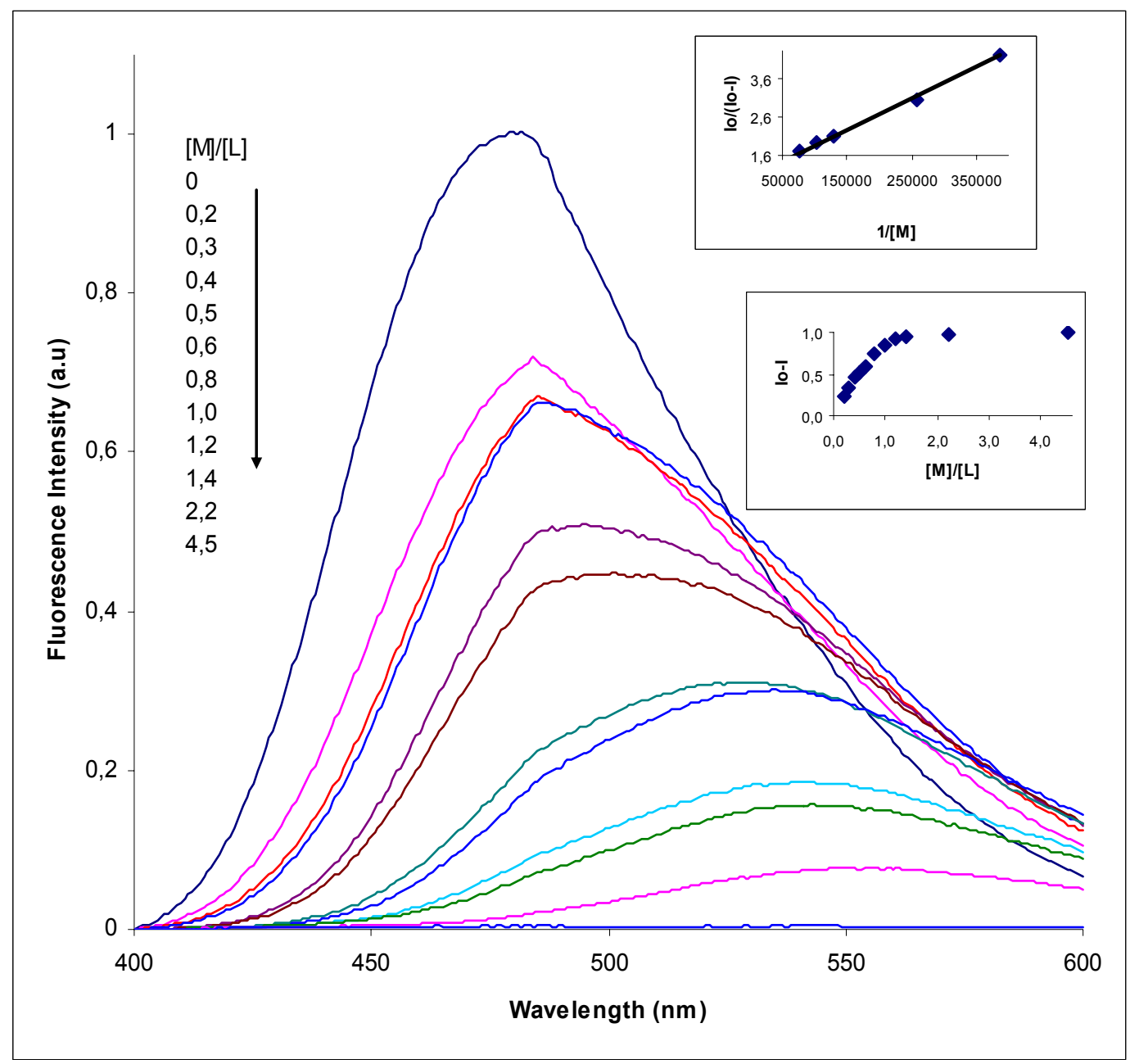

Figure 5. Fluorescence spectra of $\mathbf{L 2}$ in $\mathrm{MeCN}$ with increasing amounts of $\mathrm{Fe}^{3+}$. ([L2] $=2.58$ $\left.\mathrm{x} 10^{-5} \mathrm{M} ; \lambda_{\mathrm{exc}}=328 \mathrm{~nm} ; \lambda_{\mathrm{em}}=482 \mathrm{~nm}\right)$ 
Table 1 presents the stability constants and complex stochiometries for complexation of $\mathrm{Fe}^{3+}, \mathrm{Hg}^{2+}$ and $\mathrm{Pb}^{2+}$ by $\mathbf{L}^{16}, \mathbf{L} \mathbf{1}$ and $\mathbf{L 2}$. The $\log \beta$ values vary between 3.94 and 5.12 and show that the ionized ligands interact strongly with these metal ions in $\mathrm{MeCN}$. For 1:1 complexation of $\mathrm{Fe}^{3+}$ by the three ligands, the stability constants decrease in the order: $\mathbf{L} \mathbf{2}>\mathbf{L} \mathbf{1}>\mathbf{L}$. Thus, the attachment of either two or four allyl groups to the upper rim of di-ionized ligand $\mathbf{L}$ increases the propensity for complexation of $\mathrm{Fe}^{3+}$ in $\mathrm{MeCN}$. A similar increase of stability constant for complexation of $\mathrm{Fe}^{3+}$ was obtained with the upper-rim allyl-substituted analogues. As seen from the data in Table 1, all three ligands form 1:1 complexes with $\mathrm{Fe}^{3+}, \mathrm{Hg}^{2+}$ and $\mathrm{Pb}^{2+}$. On the other hand, the upper-rim allyl-substituted analogues formed 1:2 complexes with $\mathrm{Fe}^{3+} .{ }^{16}$ It is clear that among the ligands $\mathbf{L} 2$ forms the most stable complexes with $\mathrm{Fe}^{3+}, \mathrm{Hg}^{2+}$ and $\mathrm{Pb}^{2+}$. This result can be explained as arising from the effect of increased $\pi$ electron density due to the four benzyl groups.

Table 1. Stability constants and stoichiometries for complexation of $\mathbf{L}, \mathbf{L} \mathbf{1}$ and $\mathbf{L} 2$ with $\mathrm{Hg}^{2+}$, $\mathrm{Pb}^{2+}$ and $\mathrm{Fe}^{3+}$ in $\mathrm{MeCN}$

\begin{tabular}{|c|c|c|c|c|c|c|}
\hline & \multicolumn{3}{|c|}{$\begin{array}{c}\text { Stability constant } \\
(\log \beta) \\
\text { Cation }\end{array}$} & \multicolumn{3}{|c|}{$\begin{array}{c}\text { Complex stochiometry (M:L) } \\
\text { Cation }\end{array}$} \\
\hline Ionized ligand & $\mathrm{Fe}^{3+}$ & $\mathrm{Pb}^{2+}$ & $\mathrm{Hg}^{2+}$ & $\mathrm{Fe}^{3+}$ & $\mathrm{Pb}^{2+}$ & $\mathrm{Hg}^{2+}$ \\
\hline $\mathbf{L}$ & $3.94 \pm 0.02^{\mathrm{a}}$ & $4.76 \pm 0.04^{\mathrm{a}}$ & $4.53 \pm 0.03^{a}$ & $1: 1^{\mathrm{a}}$ & $1: 1^{\mathrm{a}}$ & $1: 1^{\mathrm{a}}$ \\
\hline L1 & $4.52 \pm 0.01$ & $3.82 \pm 0.03$ & $4.04 \pm 0.02$ & $1: 1$ & $1: 1$ & $1: 1$ \\
\hline $\mathbf{L 2}$ & $5.12 \pm 0.03$ & $5.06 \pm 0.05$ & $4.96 \pm 0.02$ & $1: 1$ & $1: 1$ & $1: 1$ \\
\hline
\end{tabular}

${ }^{\mathrm{a}}$ Reference 18.

\section{Stern-Volmer analysis}

Stern-Volmer analysis was utilized to probe the nature of the quenching process in the complexation of $\mathrm{Fe}^{3+}, \mathrm{Hg}^{2+}$ and $\mathrm{Pb}^{2+}$ by $\mathbf{L 1}$ and $\mathbf{L 2}$. Stern-Volmer plots are a useful method of presenting data on emission quenching. ${ }^{22,23}$ Plotting relative emission intensities $\left(\mathrm{I}_{\mathrm{o}} / \mathrm{I}\right)$ against quencher concentration [Q] yields a linear Stern-Volmer plot for a static quenching process. Expressed as Equation 1, the slope of this line is Ksv, the static quenching constant. $\mathrm{I}_{\text {and }} \mathrm{I}_{\mathrm{o}}$ are fluorescence intensities in the presence and in the absence of added metal cations.

$$
\mathrm{I}_{\mathrm{o}} / \mathrm{I}=1+\mathrm{Ksv}[\mathrm{Q}]
$$

Figure 6 shows the steady-state emission Stern-Volmer analysis for complexation of $\mathrm{Pb}^{2+}$ by L2. For both $\mathbf{L 1}$ and $\mathbf{L 2}$, linear behavior was observed for complexation of $\mathrm{Fe}^{3+}, \mathrm{Hg}^{2+}$ and $\mathrm{Pb}^{2+}$. These results are consistent with static quenching. 


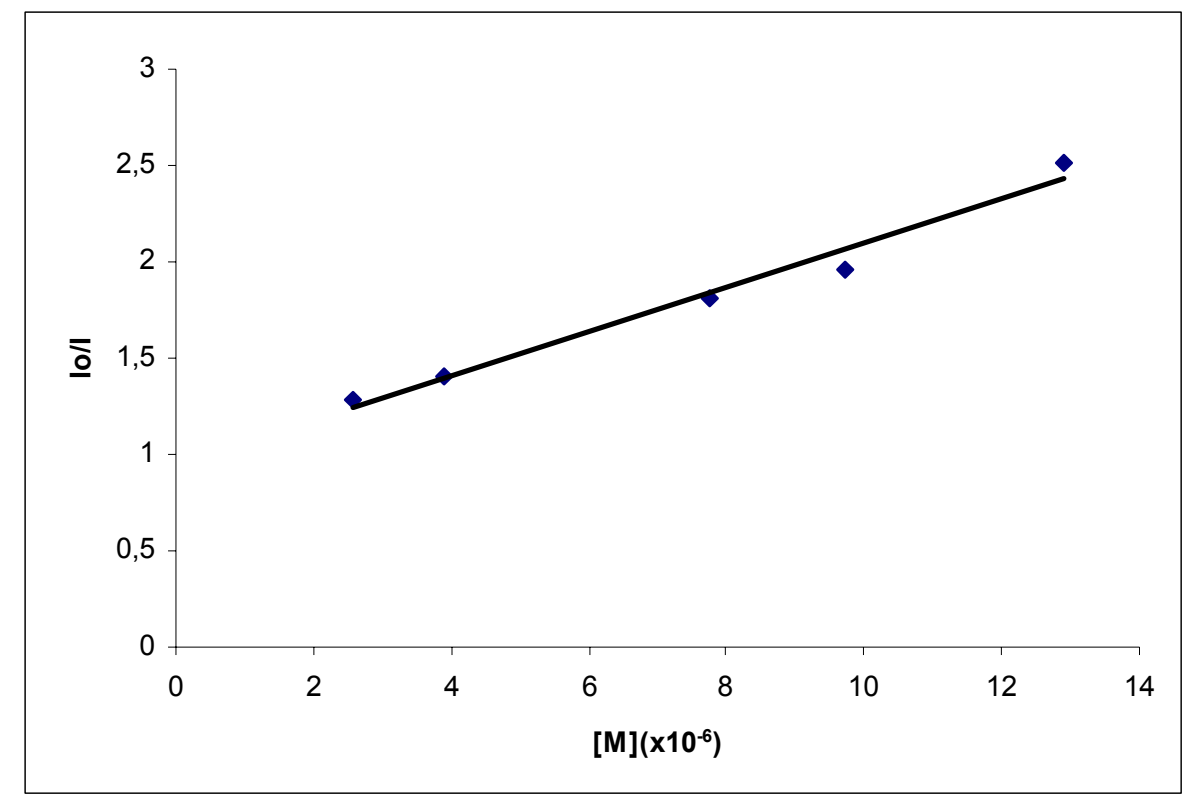

Figure 6. Stern-Volmer plot for the fluorescence quenching of $\mathbf{L} 2$ by $\mathrm{Pb}^{2+}$ in $\mathrm{MeCN}$.

\section{Summary}

This study investigates the influence of a systematic structural variation within calix[4]arene compounds with two ionized, dansyl group-containing side arms on the lower rim upon their spectroscopic responses to metal ions in MeCN. The upper rim possesses zero, two and four benzyl groups. In the presence of excess metal ions, fluorescence quenching increased in the order: alkali metal cations $<$ alkaline earth metal cations $<$ transition and heavy metal cations. The presence of $\mathrm{Fe}^{3+}, \mathrm{Hg}^{2+}$ and $\mathrm{Pb}^{2+}$ gave greater than $99 \%$ quenching of the dansyl fluorescence for the three ligands. For all three of the ionized ligands, only 1:1 (M/L) complexes are formed with these three metal ions. Information gained from this investigation aids in assessing the potential for such di-ionized, dansyl-containing ligands in fluorogenic metal ion sensors.

\section{Experimental Section}

General. The ${ }^{1} \mathrm{H}$ and ${ }^{13} \mathrm{C}$ NMR spectra were recorded with a Varian Unity INOVA $500 \mathrm{MHz}$ FT-NMR spectrometer $\left({ }^{1} \mathrm{H}\right.$ at $500 \mathrm{MHz}$ and ${ }^{13} \mathrm{C}$ at $\left.126 \mathrm{MHz}\right)$ in $\mathrm{CDCl}_{3}$ with $\mathrm{Me}_{4} \mathrm{Si}$ as internal standard. Chemical shifts $(\delta)$ are given in parts per million downfield from TMS and coupling constant $(J)$ values are in hertz. IR spectra were recorded with a Perkin-Elmer model 1600 FT-IR spectrophotometer as deposits from $\mathrm{CDCl}_{3}$ solutions on $\mathrm{NaCl}$ plates. Fluorescence spectra were obtained with a SLM Aminco 800C photon counting spectrofluorimeter equipped with a 450-W ozone-free xenon lamp as the light source. Melting points were determined with a Mel-Temp 
melting point apparatus. Elemental analysis was performed by Desert Analytics Laboratory (now Columbia Analytical Services) of Tucson, Arizona.

All reactions were conducted under nitrogen atmosphere. Reagents were obtained from commercial suppliers and used directly unless otherwise noted. Calix[4]arene 3 was obtained from Eburon Organics International of Lubbock, Texas. Tetrahydrofuran (THF) was dried over sodium with benzophenone as a indicator and distilled just before use. Spectrometric grade acetonitrile (MeCN) from EMD Chemicals was the solvent for the fluorescence measurements. All metal perchlorates purchased from Acros were of the highest available quality and vacuum dried over blue silica gel before use.

The 25,27-dihydroxy-26-28-dimethoxycalix[4]arene $4^{24}$ was prepared by a reported procedure.

\section{Fluorescence measurements}

Fluorescence spectra of the di-ionized ligands $\left(2.58 \times 10^{-5} \mathrm{M}\right)$ in $\mathrm{MeCN}$ solutions containing 50 molar equivalents of the appropriate metal perchlorate salt were measured using a 1-cm quartz cell. The excitation wavelength was $328 \mathrm{~nm}$ for all of the ionized ligands. Fluorescence emission spectra were recorded in the range $400-600 \mathrm{~nm}$ with a slit width of $1.0 \mathrm{~nm}$.

The stoichiometries of the complexes and their stability constants were determined according to a literature procedure. ${ }^{19}$

Synthesis of 11,23-dibenzoyl-25,27-dihydroxy-26,28-dimethoxycalix[4]arene (5). To a suspension of 26,28-dihydroxy-25,27-dimethoxycalix[4]arene 4 (9.59 g, $21.2 \mathrm{mmol})$ and $\mathrm{AlCl}_{3}$ (22.60 g, $84.9 \mathrm{mmol})$ in $\mathrm{CH}_{2} \mathrm{Cl}_{2}(500 \mathrm{~mL})$ was added benzoyl chloride $(23.80 \mathrm{~g}, 169.7 \mathrm{mmol})$ dropwise over a period of $30 \mathrm{~min}$. The mixture was stirred at room temperature for $24 \mathrm{~h}$ and then $5 \%$ aq $\mathrm{HCl}(50 \mathrm{~mL})$ was added. The mixture was poured into ice-water. The mixture was diluted with $1 \mathrm{~N} \mathrm{HCl}$ and extracted with $\mathrm{CH}_{2} \mathrm{Cl}_{2}(2 \mathrm{X} 400 \mathrm{~mL})$. The combined organic layers were dried over $\mathrm{MgSO}_{4}$ and evaporated in vacuo to give a yellow solid, which was recrystallized from $\mathrm{CH}_{2} \mathrm{Cl}_{2}-\mathrm{MeOH}$ to give an $81 \%$ yield of white solid with $\mathrm{mp} 289-290{ }^{\circ} \mathrm{C}$ (lit. ${ }^{20,21} \mathrm{mp}>300{ }^{\circ} \mathrm{C}$ ) . IR $3252(\mathrm{OH}), 1649(\mathrm{C}=\mathrm{O}) \mathrm{cm}^{-1} .{ }^{1} \mathrm{H}$ NMR $\delta 3.47(\mathrm{~d}, J=13.3 \mathrm{~Hz}, 4 \mathrm{H}), 4.02(\mathrm{~s}, 6 \mathrm{H}), 4.30$ (d, $J=13.2 \mathrm{~Hz}, 4 \mathrm{H}), 6.79-6.82(\mathrm{~m}, 2 \mathrm{H}), 6.91(\mathrm{~d}, J=7.6 \mathrm{~Hz}, 4 \mathrm{H}), 7.48-7.51(\mathrm{~m}, 4 \mathrm{H}), 7.56-7.60$ (m, 2H), $7.65(\mathrm{~s}, 4 \mathrm{H}), 7.74-7.76(\mathrm{~m}, 2 \mathrm{H}), 8.61(\mathrm{~s}, 2 \mathrm{H}) .{ }^{13} \mathrm{C}$ NMR $\delta$ 195.7, 157.8, 153.1, 138.7, 132.3, 131.7, 129.7, 129.4, 128.7, 128.1, 127.8, 123.6, 63.9, 31.1. Anal Calcd for $\mathrm{C}_{44} \mathrm{H}_{36} \mathrm{O}_{6} \cdot 0.2 \mathrm{CH}_{2} \mathrm{Cl}_{2}$ : C, 78.33; H, 5.41. Found: C, 78.63; H, 5.60.

Synthesis of 11,23-dibenzyl-25,27-dihydroxy-26,28-dimethoxycalix[5]arene (6). Triethylsilane $(8.65 \mathrm{~g}, 53.0 \mathrm{mmol})$ was added to a stirred suspension of 5 (5.00 g, $7.58 \mathrm{mmol})$ in $\mathrm{CF}_{3} \mathrm{CO}_{2} \mathrm{H}(100 \mathrm{~mL})$ at room temperature and the mixture was stirred for $5 \mathrm{~h}$. Then $20 \%$ aq $\mathrm{NaOH}(500 \mathrm{~mL})$ was added and the mixture was extracted with $\mathrm{CH}_{2} \mathrm{Cl}_{2}(2 \mathrm{X} 200 \mathrm{~mL})$. The combined organic layers were dried over $\mathrm{MgSO}_{4}$ and evaporated in vacuo. The red solid residue was washed with THF and the insoluble white solid was collected to give 6 as a white solid with mp 270-272 ${ }^{\circ} \mathrm{C}$ in 90\% yield. ${ }^{1} \mathrm{H}$ NMR $\delta 3.31$ (d, $\left.J=13.6 \mathrm{~Hz}, 4 \mathrm{H}\right), 3.87$ (s, 4H), $3.96(\mathrm{~s}, 6 \mathrm{H}), 4.25$ $(\mathrm{d}, J=13.1 \mathrm{~Hz}, 4 \mathrm{H}), 6.60-7.40(\mathrm{~m}, 20 \mathrm{H}), 7.73(\mathrm{~s}, 2 \mathrm{H}) .{ }^{13} \mathrm{C}$ NMR $\delta$ 153.2, 151.3, 141.9, 133.0, 
131.3, 129.0, 129.0, 128.8, 128.3, 128.0, 125.8, 125.3, 63.6, 41.0, 31.2. Anal. Calcd for $\mathrm{C}_{44} \mathrm{H}_{40} \mathrm{O}_{4}$ : C, 83.5; H, 6.37. Found: C, 83.37; H, 6.21.

Synthesis of 25,27-bis(ethoxycarboxymethoxy)-11,23-dibenzyl-26,28-dimethoxycalix[4]arene (7). To a suspension of $\mathrm{NaH}(1.26 \mathrm{~g}, 63.2 \mathrm{mmol})$ in THF $(250 \mathrm{~mL}), 6$ (4.00 g, 6.32 mmol) was added and the mixture was stirred at room temperature. When the evolution of hydrogen ceased, a solution of ethyl bromoacetate $(4.22 \mathrm{~g}, 25.28 \mathrm{mmol})$ in THF $(10 \mathrm{~mL})$ was added over a period of $30 \mathrm{~min}$. After the mixture was stirred at room temperature overnight, water was carefully added dropwise to destroy the excess $\mathrm{NaH}$. The mixture was diluted with $1 \mathrm{~N}$ $\mathrm{HCl}(200 \mathrm{~mL})$ and extracted with $\mathrm{CH}_{2} \mathrm{Cl}_{2}(2 \mathrm{X} 200 \mathrm{~mL})$. The combined organic layers were washed with water, dried over $\mathrm{MgSO}_{4}$ and evaporated in vacuo. The pale yellow solid residue was chromatographed on silica gel with $\mathrm{CH}_{2} \mathrm{Cl}_{2}$-EtOAc $(40: 1)$ as eluent to give diester 7 as a white solid with mp $154-156{ }^{\circ} \mathrm{C}$ in $71 \%$ yield. IR $1762(\mathrm{C}=\mathrm{O}) \mathrm{cm}^{-1} .{ }^{1} \mathrm{H}$ NMR $\delta 1.31(\mathrm{t}, J=7.2$, $6 \mathrm{H}), 3.00-4.60(\mathrm{~m}, 22 \mathrm{H}), 6.00-74.0(\mathrm{~m}, 20 \mathrm{H}) .{ }^{13} \mathrm{C}$ NMR $\delta 169.5,169.4,158.9,158.1,154.4$, $153.6,141.4,141.2,136.7,134.6,134.3,132.9,129.0,128.7,128.6,128.2,128.1,125.7,125.5$, 122.6, 72.1, 71.1, 60.9, 60.8, 41.0, 40.7, 30.8. Anal. Calcd for $\mathrm{C}_{52} \mathrm{H}_{52} \mathrm{O}_{8}: \mathrm{C}, 77.59 ; \mathrm{H}, 6.51$. Found: C, 77.66; H, 6.23.

Synthesis of 25,27-bis(carboxymethoxy)-11,23-dibenzyl-26,28-dimethoxycalix[4]arene (8). A mixture of diester $7(5.00 \mathrm{~g}, 6.21 \mathrm{mmol})$, THF $(250 \mathrm{~mL})$ and $10 \%$ aq $\mathrm{Me}_{4} \mathrm{NOH}(250 \mathrm{~mL})$ was refluxed overnight. The mixture was acidified to $\mathrm{pH} \sim 1$ with $10 \%$ aq $\mathrm{HCl}$. The solvent was removed in vacuo and $\mathrm{CH}_{2} \mathrm{Cl}_{2}(2 \mathrm{X} 200 \mathrm{~mL})$ was added. The combined organic layers were washed with water, dried over $\mathrm{MgSO}_{4}$ and evaporated in vacuo to give diacid $\mathbf{8}$ as a white solid with mp 191-192 ${ }^{\circ} \mathrm{C}$ in 97\% yield. IR 3760-2505 (O-H), $1757(\mathrm{C}=\mathrm{O}) \mathrm{cm}^{-1} .{ }^{1} \mathrm{H}$ NMR $\delta 3.27$ (d, $J=13.2$, 4H) $3.81(\mathrm{~s}, 6 \mathrm{H}), 1.96$ (s, 4H), 4.19 (d, $J=13.2,4 \mathrm{H}), 4.67$ (s, 4H), 6.20-7.15 (m, 20H). ${ }^{13} \mathrm{C}$ NMR $\delta$ 169.6, 154.1, 141.0, 137.5, 134.9, 132.6, 130.0, 128.9, 128.8, 128.7, 128.5, 126.2, 124.4, 72.1, 63.8, 41.2, 30.7. Anal. Calcd for $\mathrm{C}_{48} \mathrm{H}_{44} \mathrm{O}_{8} \bullet \mathrm{CH}_{2} \mathrm{Cl}_{2}$ : C, 76.28; H, 5.88. Found: 76.01; H, 6.28.

Synthesis of 25,27-bis[ $N$-(5-dimethylaminonaphthalene-1-sulfonyl)carbamoylmethoxy]11,23-dibenzyl-26,28-dimethoxycalix[4]arene (1). Diacid 8 (0.50 g, $0.67 \mathrm{mmol})$ was dried by benzene-azeotropic distillation with a Dean-Stark trap. Oxalyl chloride $(0.57 \mathrm{~mL}, 6.7 \mathrm{mmol})$ was added and the solution was refluxed for $5 \mathrm{~h}$. The solvent was removed in vacuo to provide the corresponding di(acid chloride). A solution of the di(acid chloride) in THF (20 mL) was added to a mixture of dansylamide $(0.37 \mathrm{~g}, 1.48 \mathrm{mmol})$ and $\mathrm{NaH}(0.16 \mathrm{~g}, 6.7 \mathrm{mmol})$ in THF $(20 \mathrm{~mL})$. The mixture was stirred overnight at room temperature. Water was added carefully dropwise to decompose the excess $\mathrm{NaH}$. The THF was evaporated in vacuo and $\mathrm{CH}_{2} \mathrm{Cl}_{2}(100 \mathrm{~mL})$ was added to the residue. The organic layer was washed with $1 \mathrm{~N} \mathrm{HCl}(50 \mathrm{~mL})$ and then water $(2 \mathrm{X} 50 \mathrm{~mL})$, dried over $\mathrm{MgSO}_{4}$ and evaporated in vacuo. The residue was chromatographed on silica gel with $\mathrm{CH}_{2} \mathrm{Cl}_{2}$-EtOAc (3:1) as eluent. Appropriate fractions were combined and evaporated in vacuo. The residue was dissolved in $\mathrm{CH}_{2} \mathrm{Cl}_{2}$. The solution was washed with $10 \%$ aq $\mathrm{HCl}$ and then water, dried over $\mathrm{MgSO}_{4}$ and evaporated in vacuo to give a 30\% yield of $\mathbf{1}$ as a light yellow solid with mp 172-174 ${ }^{\circ} \mathrm{C}$. IR 3453 and $3327(\mathrm{~N}-\mathrm{H}), 1729(\mathrm{C}=\mathrm{O}) \mathrm{cm}^{-1} .{ }^{1} \mathrm{H}$ NMR $\delta$ 2.90-3.90 (m, 34H), 
6.20-7.95 (m, 26H), 8.67 (s, 1H), 8.68 (s, 1H), 8.86 (br s, 2H), 9.08 (br s, 2H), 9.68 (br s, 2H).

${ }^{13} \mathrm{C}$ NMR $\delta 167.2,151.8,141.0,135.6,133.7,129.9,129.8,128.9,128.6,126.0,46.5,41.0,31.9$, 29.7, 29.3, 27.2, 26.7, 22.7, 14.1. Anal. Calcd for $\mathrm{C}_{72} \mathrm{H}_{68} \mathrm{~N}_{4} \mathrm{O}_{10} \mathrm{~S}_{2}$ : C, 71.26; H, 5.65; N, 4.62. Found: C, 71.50; H, 5.75; N, 4.50.

Synthesis of 5,11,17,23-tetrabenzoyl-25,26,27,28-tetrahydroxycalix[4]arene (9). To a suspension of calix[4]arene $3(5.00 \mathrm{~g}, 11.8 \mathrm{mmol})$ and $\mathrm{AlCl}_{3}(12.60 \mathrm{~g}, 94.4 \mathrm{mmol})$ in $\mathrm{CH}_{2} \mathrm{Cl}_{2}$ $(250 \mathrm{~mL})$ was added benzoyl chloride $(26.52 \mathrm{~g}, 188.7 \mathrm{mmol})$ dropwise over a period of $30 \mathrm{~min}$. The mixture was stirred at room temperature for $24 \mathrm{~h}$ and then poured into ice-water. The organic layer was separated, washed with $1 \mathrm{~N} \mathrm{HCl}$ and then with $10 \%$ aq $\mathrm{NaOH}$ (to remove the excess benzoyl chloride) and evaporated in vacuo. The yellow solid residue was mixed with $\mathrm{MeOH}(600 \mathrm{~mL})$ and $10 \%$ aq $\mathrm{NaOH}(200 \mathrm{~mL})$ and the mixture was refluxed for 2 days. The $\mathrm{MeOH}$ was evaporated in vacuo. The precipitate was filtered to give a yellow solid, which was added to $\mathrm{CH}_{2} \mathrm{Cl}_{2}(1500 \mathrm{~mL})$ and $1 \mathrm{~N} \mathrm{HCl}(500 \mathrm{~mL})$. Upon stirring the mixture overnight, the solid dissolved completely. The $\mathrm{CH}_{2} \mathrm{Cl}_{2}$ layer was separated, washed with water, dried over $\mathrm{MgSO}_{4}$ and evaporated in vacuo to give a red solid. Chromatography on silica gel with $\mathrm{CH}_{2} \mathrm{Cl}_{2}-$ $\mathrm{MeOH}(80: 1)$ as eluent gave an $89 \%$ yield of 9 as a white solid with mp $326-328{ }^{\mathrm{O}} \mathrm{C}$ (lit. ${ }^{25} \mathrm{mp}$ 332-334 ${ }^{\circ} \mathrm{C}$, lit. ${ }^{21} \mathrm{mp} 176-178{ }^{\circ} \mathrm{C}$ ). Alternatively, recrystallization from $\mathrm{CH}_{2} \mathrm{Cl}_{2}-\mathrm{MeOH}$ gave the product in 80\% yield. IR $3208(\mathrm{O}-\mathrm{H}), 1650(\mathrm{C}=\mathrm{O}) \mathrm{cm}^{-1} .{ }^{1} \mathrm{H}$ NMR $\delta 3.73(\mathrm{~d}, J=12.4 \mathrm{~Hz}, 4 \mathrm{H})$, 4.33 (d, $J=12.0 \mathrm{~Hz}, 4 \mathrm{H}) 7.41-7.68$ (m, 28H), 10.16 (br s, 4H). ${ }^{13} \mathrm{C}$ NMR $\delta 194.9,137.4,132.4$, 131.8, 129.9, 128.4, 96.1, 53.4, 31.4. Anal. Calcd for $\mathrm{C}_{56} \mathrm{H}_{40} \mathrm{O}_{8}$ : C, 79.98; H, 4.79. Found: C,80.03; H, 4.90 .

Synthesis of 5,11,17,23-tetrabenzyl-25,26,27,28-tetrahydroxycalix[4]arene (10). To a suspension of $9(5.00 \mathrm{~g}, 5.95 \mathrm{mmol})$ and $\mathrm{K}_{2} \mathrm{CO}_{3}(16.43 \mathrm{~g}, 119.0 \mathrm{mmol})$ in triethylene glycol (300 $\mathrm{mL})$ was added hydrazine hydrate $(20 \mathrm{~mL})$. The mixture was heated to reflux and water was removed with a Dean-Stark trip. When no additional amount of water was evolved, the DeanStark trap was removed and the mixture was refluxed for $20 \mathrm{~h}$ and then allowed to cool to room temperature. The mixture was diluted with $1 \mathrm{~N} \mathrm{HCl}(200 \mathrm{~mL})$ and extracted with $\mathrm{CH}_{2} \mathrm{Cl}_{2}(2 \mathrm{X}$ $200 \mathrm{~mL}$ ). The combined organic layers were washed with water, dried over $\mathrm{MgSO}_{4}$ and evaporated in vacuo. The yellow solid residue was chromatographed on silica gel with hexanes$\mathrm{CH}_{2} \mathrm{Cl}_{2}$ (2:1) as eluent to give $\mathbf{1 0}$ as a white solid with $\mathrm{mp} 192-194{ }^{\circ} \mathrm{C}$ (lit. ${ }^{26} \mathrm{mp} 204.5-205.6{ }^{\circ} \mathrm{C}$ ) in 95\% yield. IR $3172(\mathrm{O}-\mathrm{H}) \mathrm{cm}^{-1} .{ }^{1} \mathrm{H}$ NMR $\delta 3.36(\mathrm{~d}, J=12.7 \mathrm{~Hz}, 4 \mathrm{H}), 3.76(\mathrm{~s}, 8 \mathrm{H}), 4.15(\mathrm{~d}$, $J=12.7 \mathrm{~Hz}, 4 \mathrm{H}), 6.78$ (s, 8H), 7.08-7.32 (m, 20H), 10.13 (s, 4H). ${ }^{13} \mathrm{C}$ NMR $\delta 147.1,141.1,134.5$, 129.3, 128.9, 128.4, 128.2, 126.0, 53.4, 41.0, 31.7. Anal. Calcd for $\mathrm{C}_{56} \mathrm{H}_{48} \mathrm{O}_{4} \bullet 0.1 \mathrm{CH}_{2} \mathrm{Cl}_{2}$ : C, 84.92; H, 6.12. Found: C, 84.58; H, 5.96.

Synthesis of 26,28-dihydroxy-25,27-dimethoxy-5,11,17,23-tetrabenzylcalix[4]arene (11). To a suspension of $10(3.20 \mathrm{~g}, 4.08 \mathrm{mmol})$ in $\mathrm{MeCN}(200 \mathrm{~mL})$ was added $\mathrm{K}_{2} \mathrm{CO}_{3}(0.62 \mathrm{~g}, 4.48$ $\mathrm{mmol})$ and $\mathrm{MeI}(1.27 \mathrm{~g}, 8.98 \mathrm{mmol})$. The mixture was refluxed for $20 \mathrm{~h}$ and then allowed to cool to room temperature. The mixture was evaporated in vacuo and the residue was partitioned between $\mathrm{CH}_{2} \mathrm{Cl}_{2}(200 \mathrm{~mL})$ and $1 \mathrm{~N} \mathrm{HCl}(200 \mathrm{~mL})$. The organic layer was separated, washed with water, dried over $\mathrm{MgSO}_{4}$ and evaporated in vacuo. The residue was chromatographed on silica 
gel with hexanes-EtOAc (30:1) as eluent to give 11 as a white solid with mp $102-104{ }^{\circ} \mathrm{C}$ in $91 \%$ yield. IR $3353(\mathrm{O}-\mathrm{H}) \mathrm{cm}^{-1} .{ }^{1} \mathrm{H}$ NMR $\delta 3.25$ (d, $\left.J=12.9 \mathrm{~Hz}, 4 \mathrm{H}\right), 3.64$ (s, 4H), 3.84 (s, 4H), 3.93 (s, 6H), $4.21(\mathrm{~d}, J=12.9 \mathrm{~Hz}, 4 \mathrm{H}), 6.67(\mathrm{~s}, 4 \mathrm{H}), 6.82(\mathrm{~s}, 4 \mathrm{H}), 6.97-7.01(\mathrm{~m}, 4 \mathrm{H}), 7.10-7.31$ (m, 16H), 7.87 (s, 2H). ${ }^{13} \mathrm{C}$ NMR $\delta 151.7,151.2,141.7,141.2,133.1,131.3,129.5,129.0,128.9$, 128.7, 128.4, 128.3, 128.2, 125.9, 125.8, 63.5, 41.3, 41.0, 31.3. Anal. Calcd for $\mathrm{C}_{58} \mathrm{H}_{52} \mathrm{O}_{4}$ : C, 85.68; H, 6.45. Found: C, 85.89; H, 6.73.

Synthesis of 25,27-di(ethoxycarboxymethoxy)-26,28-dimethoxy-5,11,17,23-tetrabenzylcalix[4]arene (12). To a suspension of $\mathrm{NaH}(0.51 \mathrm{~g}, 21.4 \mathrm{mmol})$ in THF (100 mL), 11 (4.35 g, 5.36 mmol) was added and the mixture was stirred at room temperature until the evolution of hydrogen ceased. A solution of ethyl bromoacetate $(3.58 \mathrm{~g}, 21.4 \mathrm{mmol})$ in THF (10 mL) was added over a period of $30 \mathrm{~min}$ and the mixture was stirred overnight at room temperature. Water was carefully added dropwise to destroy the excess $\mathrm{NaH}$. The mixture was diluted with $1 \mathrm{~N} \mathrm{HCl}$ $(200 \mathrm{~mL})$ and extracted with $\mathrm{CH}_{2} \mathrm{Cl}_{2}(2 \mathrm{X} 200 \mathrm{~mL})$. The combined organic layers were washed with water, dried over $\mathrm{MgSO}_{4}$ and evaporated in vacuo. The residue was chromatographed on silica gel with hexanes-EtOAc (30:1) as eluent to give 12 in $90 \%$ yield as an oil. IR $1759(\mathrm{C}=\mathrm{O})$ $\mathrm{cm}^{-1} .{ }^{1} \mathrm{H}$ NMR $\delta 1.27(\mathrm{t}, 6 \mathrm{H}), 2.60-4.60(\mathrm{~m}, 30 \mathrm{H}), 6.17-7.41(\mathrm{~m}, 28 \mathrm{H}) .{ }^{13} \mathrm{C} \mathrm{NMR} \delta 169.4,157.1$, $154.7,153.6,142.0,141.3,136.6,134.8,134.6,134.3,132.9,129.5,129.3,129.0,128.8,128.6$, 128.3, 128.2, 128.1, 128.0, 125.9, 125.7, 125.6, 72.1, 70.9, 60.8, 53.4, 41.3, 41.0, 40.9, 30.8. Anal. Calcd for $\mathrm{C}_{66} \mathrm{H}_{64} \mathrm{O}_{8}$ : C, 80.46; H, 6.55. Found: C, 80.11; H, 6.38.

Synthesis of 25,27-di(carboxymethoxy)-26,28-dimethoxy-5,11,17,23-tetrabenzylcalix[4]arene (13). A mixture of 12 (5.00 g, $5.07 \mathrm{mmol})$, THF (150 mL) and 10\% aq $\mathrm{Me}_{4} \mathrm{NOH}$ (100 $\mathrm{mL}$ ) was refluxed overnight. The mixture was acidified to $\mathrm{pH} \sim 1$ with $10 \%$ aq $\mathrm{HCl}$. The solvent was evaporated in vacuo to give 13 as a yellowish solid with mp $96-100{ }^{\circ} \mathrm{C}$ in $97 \%$ yield. IR 3730-2520 (O-H), $1753(\mathrm{C}=\mathrm{O}) \mathrm{cm}^{-1} .{ }^{1} \mathrm{H}$ NMR $\delta 3.22$ (d, J=13.2 Hz, 4H), 3.46 (s, 4H), 3.79 (s, $4 \mathrm{H}), 3.88(\mathrm{~s}, 4 \mathrm{H}), 4.16(\mathrm{~d}, J=13.2 \mathrm{~Hz}, 4 \mathrm{H}), 4.65(\mathrm{~s}, 4 \mathrm{H}), 6.22-7.36(\mathrm{~m}, 28 \mathrm{H}) .{ }^{13} \mathrm{C}$ NMR $\delta 169.6$, $153.9,151,4,141.2,140.7,137.5,136.3,135.0,132.5,129.9,129.2,128.7,128.5,128.4,128.3$, 126.2, 125.9, 72.1, 63.8, 41.1, 40.8, 30.62. Anal. Calcd for $\mathrm{C}_{67} \mathrm{H}_{56} \mathrm{O}_{8} \bullet 0.3 \mathrm{CH}_{2} \mathrm{Cl}_{2}$ : C, 78.38; $\mathrm{H}$, 5.98. Found: C, 78.66; H, 6.08 .

Synthesis of 25,27-bis[N-(5-dimethylaminonaphthalene-1-sulfonyl)carbamoylmethoxy]$\mathbf{5 , 1 1 , 1 7 , 2 3 - t e t r a b e n z y l - 2 6 , 2 8 - d i m e t h o x y c a l i x [ 4 ] a r e n e ~ ( 2 ) . ~ D i a c i d ~} 13$ (0.30 g, $0.32 \mathrm{mmol})$ was dried by benzene-azeotropic distillation with a Dean-Stark trap. Oxalyl chloride $(0.28 \mathrm{~mL}, 3.3$ mmol) was added and the solution was refluxed for $5 \mathrm{~h}$. The solvent was removed in vacuo to provide the corresponding di(acid chloride). A solution of the di(acid chloride) in THF (20 $\mathrm{mL}$ ) was added to a mixture of dansylamide $(0.18 \mathrm{~g}, 0.72 \mathrm{mmol})$ and $\mathrm{NaH}(0.080 \mathrm{~g}, 3.3 \mathrm{mmol})$ in THF $(20 \mathrm{~mL})$. The mixture was stirred overnight at room temperature. Water was added carefully dropwise to decompose the excess $\mathrm{NaH}$. The THF was evaporated in vacuo and $\mathrm{CH}_{2} \mathrm{Cl}_{2}$ $(100 \mathrm{~mL})$ was added to the residue. The organic layer was washed with $1 \mathrm{~N} \mathrm{HCl}(50 \mathrm{~mL})$ and then water ( $2 \mathrm{X} 50 \mathrm{~mL}$ ), dried over $\mathrm{MgSO}_{4}$ and evaporated in vacuo. The residue was chromatographed on silica gel with $\mathrm{CH}_{2} \mathrm{Cl}_{2}$-EtOAc (2:1) as eluent. Appropriate fractions were combined and evaporated in vacuo. The residue was dissolved in $\mathrm{CH}_{2} \mathrm{Cl}_{2}$. The solution was 
washed with $10 \%$ aq $\mathrm{HCl}$ and then water, dried over $\mathrm{MgSO}_{4}$ and evaporated in vacuo to give a $40 \%$ yield of 2 as a light yellow solid with mp 149-151 ${ }^{\circ} \mathrm{C}$. IR $3355(\mathrm{~N}-\mathrm{H}), 1731(\mathrm{C}=\mathrm{O}) \mathrm{cm}^{-1} .{ }^{1} \mathrm{H}$ NMR $\delta 2.78-4.00(\mathrm{~m}, 34 \mathrm{H}), 6.60-8.10(\mathrm{~m}, 38 \mathrm{H}), 8.50-9.20(\mathrm{~m}, 6 \mathrm{H}), 9.94(\mathrm{br} \mathrm{s}, 2 \mathrm{H}) .{ }^{13} \mathrm{C}$ NMR $\delta$ $168.1,156.7,151.8,141.8,141.3,137.4,135.5,135.0,133.5,132.3,131.2,130.0,129.8,128.9$, 128.7, 128.6, 128.5, 128.4, 128.3, 128.2, 125.9, 125.8, 58.1, 46.0, 41.0, 40.4, 32.3, 29.7, 22.7, 14.1. Anal. Calcd for $\mathrm{C}_{86} \mathrm{H}_{80} \mathrm{~N}_{4} \mathrm{O}_{10} \mathrm{~S}_{2}$ : C, 72.28; H, 5.64; N, 3.92. Found: C, 71.95; H, 5.65; N, 4.10 .

Synthesis of the di(tetramethylammonium) salts of the di-ionized ligands L1 and L2. Di(tetramethylammonium) salts of ligands $\mathbf{1}$ and $\mathbf{2}$ (L1 and L2, respectively) were prepared according to a published procedure. ${ }^{18}$

\section{Acknowledgements}

This work was supported by The Scientific and Technological Research Council of Turkey (TUBITAK). We also thank the Division of Chemical Sciences, Geosciences and Biosciences of the Office of Basic Energy Sciences of the U.S. Department of Energy (Grant DE-FG0290ER14416) for support of this research. AHG was supported by the Welch Summer Scholar Program of The Welch Foundation.

\section{References}

1. Ikeda, A.; Tsudera, T.; Shinkai, S. J. Org. Chem. 1997, 62, 3568.

2. Kim, J. S.; Noh, K. H.; Lee, S. H.; Kim, S. K.; Kim, S. K.; Yoon. J. J. Org. Chem. 2003, 68, 597.

3. Kim, J. S.; Shon, O. J.; Rim, J. A.; Kim, S. K.; Yoon, J. J. Org. Chem. 2002, 67, 2348.

4. Goodwin, P. M.; Ambrose, W. P.; Keller, R. A. Acc. Chem. Res. 1996, 29, 607.

5. Desvergne, J. P.; Czarnik, A. W., Eds. NATO ASI Series, Series C; Kluwer: Dordrecht, The Netherlands, 1997; Vol. 492, pp 23-35.

6. Valeur, B.; Leray, I. Coord. Chem. Rev. 2000, 205, 3.

7. Kim, S.K.; Lee, J. K.; Lim, J.M.; Kim, J.W.; Kim, J.S. Bull. Korean Chem. Soc. 2004, 25, 1247.

8. Osipov, M.; Chu, Q.; Geib, S.J.; Curan, D.P.; Weber, S.G. Beilstein J. Org.Chem. 2008, 4.

9. Leray, I.; Lefevre, J.P.; Delouis, J.F.; Delaire, J.; Valeur, B. Chem. Eur. J. 2001, 7, 4590.

10. Agrawal,Y. K.; Pancholi, J. P. Synth. Commun. 2008, 38, 2446.

11. Gutsche, C. D. Calixarenes, Royal Society of Chemistry, Cambridge, England, 1989.

12. Yukihiro Okada, Y.; Mizutani, M.; Ishii, F.; Kasai, Y.; Nishimurap, J. Tetrahedron 2001, 57, 1219.

13. Guelzim, A.; Saadioui, M.; Asfari, Z.; Vicens J. J. Incl. Phenom. 2001, 39, 91. 
14. Yang, F. F.; Zhao, X.; Huang, C.Y.; Guo, H. Y.; Zheng, S. N.; Peng, X. Chin. Chem .Lett. 2006, 17, 1029.

15. Roundhill, D. M. In Progress in Inorganic Chemistry; Karlin, K. D., Ed.; Wiley Interscience, 2007; Vol. 43, pp 533-592.

16. Ocak, Ü.; Ocak, M.; Surowiec, K.; Liu, X.; Bartsch, R.A. Tetrahedron 2009, 65, 7038.

17. Kumar, C.; Chawla, H. M.; Varadarjan, R. Tetrahedron Lett. 2002, 43, 2495.

18. Ocak, Ü.; Ocak, M.; Surowiec, K.; Bartsch, R. A.; Gorbunova, M. G.; Tu, C.; Surowiec, M. A . J. Incl. Phenom. Macrocycl. Chem. 2009, 63, 131.

19. Bourson, J.; Valeur, B. J. Phys. Chem. 1989, 93, 3871.

20. Huang, Z.; Wang, G. J. Chem. Soc., Perkin Trans. 1 1993, 167.

21. Huang, Z.; Wang, G. Chem. Ber. 1994, 127, 519.

22. Murphy, C.B.; Zhang, Y.; Troxler, T.; Ferry, V.; Martin, J.J.; Jones, W.E. J. Phys. Chem. B 2004, 108, 1537.

23. Larsen, R.W.; Helms, M.K.; Everett, W.R.; Jameson, D.M. Photochem. Photobiol. 1999, 69, 429.

24. von Loon, J. D.; Arduini, A.; Coppi, L.; Verboom, W.; Pochini, A.; Ungaro, R.; Harkema, S.; Reinhoudt, D. N. J. Org. Chem. 1990, 55, 5639.

25. Gutsche, C. D.; Pagoria, P. F. J. Org. Chem. 1985, 50, 5795.

26. Makha, M.; Raston, C. L. Chem. Commun. 2001, 2470. 